\title{
AN ANALYTICAL FRAMEWORK FOR SUSTAINABILITY OF INTENSIVE RICE PRODUCTION AND FARMERS' LIVELIHOOD
}

\author{
Nguyen Huu Dung \\ University of Economics Hochiminh City \\ (Manuscript Received on April 19 ${ }^{\text {th }}, 2011$, Manuscript Revised October 21 $1^{\text {st }}$, 2011)
}

\begin{abstract}
In most intensive rice-farming regions, the use of agrochemicals (chemical fertilizers and pesticides) has shown two contradictory outcomes - a positive contribution to total rice productivity but a negative effect on human health and the environment. The main objective of this paper is to set out an analytical framework for measuring and analysing the sustainable aspect of agrochemicals use in rice production and their effects on the environment. The framework is built upon the controversy concept of intensive rice production, agricultural externality, and sustainability which has been used to provide a perspective and focused on development. Thus, it takes into account the relationship between technical, economic and environmental aspects and policy in one integrated analysis, something that has not been done in the literature in Vietnam so far. Private profitability of rice farmers and the possible negative effects of agrochemical use are suggested to be examined at farm level.
\end{abstract}

Key word: agrochemicals, intensive-rice production, sustainable development.

\section{INTENSIVE RICE PRODUCTION}

Agricultural production is one of the oldest productive activities of human beings. Traditionally, people relied on biophysical conditions, local varieties and resources, and their knowledge and experience to produce food and fibres for their own needs and consumption. Such farming, referred to as traditional or extensive agriculture, is more dependent on internal inputs than modern agriculture. It has limited productivity and generates few external impacts (Conway and Pretty, 1991: 1-16). Some traditional agriculture comprises efficiently managed systems which have hit a yield ceiling and need modernization (Pretty, 1995: 27-57). Farming systems in these areas are complex and diverse; agricultural production and rural livelihoods are often dependent on natural resources. However, production in these areas receives less support from scientists and research institutions and suffers from poor infrastructure and inadequate access to markets. Consequently, productivity is low there, with cereal yields typically less than 1 ton per hectare. The floating-rice system in the Mekong Delta is an example of this traditional agriculture, its rice yield averaging 1.5 ton per hectare. This system almost disappeared in the late 1990s.

Trang 26 
With the dramatic population increase in developing countries and growing worldwide need for food over the past 50 years, agricultural production has been increased through technological breakthroughs. Modern agriculture is characterized by higher productivity and heavy dependence on external inputs, especially seeds, pesticides, chemical fertilizers, irrigation, tractors and other machines. Following the Green Revolution in developing countries, high-external input systems are found mostly in irrigated plains and deltas. Farmers tend to practise intensive mono-cropping systems using modern highyield plant varieties as well as expensive external inputs, including chemical fertilizers, pesticides, machinery and water irrigation. The intensification of rice farming in the Mekong Delta is an example of agricultural modernization in Vietnam.

Many terms, such as sustainable, alternative, ecological, biological, intensive, and regenerating agriculture, are used to describe alternatives to modern farming. Groups and institutions use the term that is most in accord with their different interests and they often present diverse aspects of modern agriculture in terms of resource use and environmental protection.

This paper focuses on the context of highinput intensive agriculture. Intensive rice cultivation is the outcome of the movement from traditional systems relying on internal resources towards multi-harvest cultivation systems where plots of land are continuously cultivated with abuse of external inputs, such as High Yielding Varieties (HYV) seeds, chemical fertilizers and pesticides. However, not all rice farmers in the Mekong Delta have adopted high-external input technology. Intensive rice cultivation not only increases yields, quality and profitability, it also leads to increasing environmental problems which could threaten productivity and the health and wellbeing of farmers in the future. Therefore, sustainable development of rice cultivation in the Mekong Delta is uncertain.

\section{SUSTAINABLE DEVELOPMENT}

The analytical framework of this paper is built upon the controversy concept of sustainability. This concept has been used to provide a perspective and focused on development. The concept and discussion in this part are based mostly on the relatively new concept of 'sustainability' in the report 'Our Common Future', and partly on Opschoor (2002: 79-99). There are three main aspects to sustainability: ecological, social and economic. Economic sustainability focuses on the maintenance of a set of factors of production large enough to ensure that there will be no future negative changes in income or welfare per capita for several decades; environmental sustainability implies maintenance of the lifesupporting environment essential for production and the continued existence of humanity or life in general. Social sustainability refers to the maintenance of societal conditions and institutions that are favourable to meet human needs and 
aspirations of future generations as well as current ones. These aspects are elucidated further below.

The notion of sustainability remained dormant for a long time until the late 1970s, when the World Conservation Strategy (ICUNUNEP-WWF, 1980) explicitly claimed that for development to be sustainable it should take into account social and ecological factors as well as economic ones, in both short-term as well as long-term perspectives. The evolution of the concept was reached with the publication of the so-called Brundtland Report of the World Commission on Environment and Development, Our Common Future (WCED, 1987), which proposed a more tangible definition:

Sustainable development is a process of change in which the exploitation of resources, the direction of investment, the orientation of technological development, and institutional change are all compatible and enhance both current and future potential to meet human needs and aspirations (WCED, 1987: 46).

The most important innovation in the notion is a concern over the future impacts of events set in motion in the present. It looks at intertemporal aspects of possible patterns of development, and goes much further than the standard economic calculus in that it explicitly attempts to bring in intergenerational considerations. In looking at intertemporal and intergenerational issues, sustainable development only allows for non-negative changes in resource endowment, which is a potentially powerful stance on intergenerational equity. However, the conceptual development around 'sustainability' has a number of features that regrettably diminish its clarity. In addition, the scope of sustainability has also extended beyond the domain of natural resource utilization and management to encapsulate other environmental concerns (for example with regard to pollution and waste) and ecological conditions and processes in general.

Anthropocentric viewpoints on sustainability, such as that of the Brundtland Report, are founded on economic concepts, focusing on moral adjustments about the wellbeing of people and placing mankind at the centre of analysis. The economic concept of sustainability may also be broadly interpreted to mean that the standard of living or economic welfare of future generations will not be less than that of the present generations. Welfare is the result of development of a whole range of different types of resources, including natural ones. Discussions about these resources with regard to their availability distinguish three types of capital: human capital (in terms of qualities and quantities of labour, skill and knowledge), physical (or 'product') capital, and natural capital, which are substitutes for each other to a significant degree. Because of this substitutability, a distinction is made between 'weak' and 'strong' conditions for sustainability in the environmental economic literature. In a situation of weak sustainability, there are no limits to the possibility of

\section{Trang 28}


substituting man-made capital (physical and human capital) for natural capital and substitution as a way of sustaining the income of future generations. In contrast, strong sustainability (or ecological sustainability) is possible when substitution between the capital stocks is strictly limited or not allowed, and kept at least constant over time, and natural resources impose an absolute constraint on development paths. In this light, it is important to keep in mind that a strict application of the Brundtland definition of sustainable development 'only calls for concern over sustainability in its weak form' (Opschoor, 2002: 84).

\section{SUSTAINABILITY OF INTENSIVE RICE CULTIVATION}

Rice cultivation as a dominant economic activity in the Mekong Delta is greatly dependent on natural capital (that is, living organisms, biophysical processes and conditions in which rice is grown). Bad weather, soil erosion or severe pest/disease infection can affect harvests. This also applies to most other agricultural production activities. The substitution of natural capital with manmade capital, such as chemical fertilizers for natural nutrients, or pesticides for natural enemies/predators in the rice fields, provides high yields, but at a cost to the ecosystem and the environment. Thus, man-made capital cannot be easily substituted for natural capital in agriculture.

There have been many efforts to explain and define sustainable agriculture development, with each definition emphasizing different values, priorities and goals. However, they all emphasize, more or less, the three dimensions mentioned earlier: economic, environmental and social. No well-defined comprehensive concept seems to have been proposed so far and the meaning of sustainability depends on whether its definition is based upon social, economic or environmental sustainability or a combination of all three (for example, sustainable community, sustainable forestry, sustainable agriculture, sustainable land use, and sustainable nutrient management).

In this paper, sustainable agriculture refers to rice-based production systems that attempt to provide long-term continuous yields and economic viability while being social acceptable and avoiding environmental degradation. This requires a combination of three common perspectives of sustainability to assess the performance of rice production in the Mekong Delta. Yield is an important indicator of any production system, reflecting the rate and constancy of its production and affecting profitability. Farmers would like rice yields and production to increase over time or at least remain constant. However, it is worth noting that not all farmers seek high yields, but many farmers, especially in small farms place higher value on risk minimization than maximizing production.

From an economic point of view, agricultural techniques are unlikely to be adopted by farmers unless they are economically viable. The profitability of rice production depends not 
only on physical factors (that is, yield and production) but also on market-related factors (that is, price levels of inputs and outputs, trends in prices and access to markets). Many economic studies of rice production in developing countries show that farmers try to maximize profits and adjust their input use in response to price signals in the market. However, economic profits for farmers, while being necessary for rice production to be sustained do not mean that the economic returns to society are positive. Some private costs are passed on to others due to production externalities (for example, health costs due to exposure to pesticides, and water contamination). In the Mekong Delata, health cost is estimated to increase by 0.934 per cent for every 1 per cent increase in total dose of pesticides (Dung, 2007). Externalities are an important source of environmental degradation, as will be demonstrated in the next section. Since output (for example, yields) and farmers' incomes are much dependent on natural resources, they can fall sharply when these resources decline, leading to social consequences. Society may not accept intensive rice cultivation if it does not provide farm families with higher incomes or narrow the income gap among farmers. Hence, social acceptability and avoidance of environmental degradation should be analysed thoroughly when accessing the sustainability of intensive rice cultivation, instead of focusing simply on economic viability and yields.

\section{EXTERNALITIES OF}

AGROCHEMICALS USED IN RICE PRODUCTION

It is obvious that agrochemicals play a major role in agriculture globally. Agrochemicals provide nutrients to crops (through application of fertilizers), and reduce pests and disease (through the use of pesticides) and thus have contributed significantly to increasing crop yields and farm profitability. Rice farmers who use fertilizers to improve yields, especially of high-yielding varieties, can compensate for nutrients lost as a result of leaching and maintain soil fertility for subsequent cropping seasons. The use of pesticides has helped to maintain/improve yields by eliminating or reducing competition from weeds and attacks by disease and rice pest. From a microeconomic perspective, a farmer's economic returns increase with use of agrochemicals until a level where the marginal benefit of application equals the marginal cost of application. Dung ((2007) found that rice farmers in the Mekong Delta responsed rationally to market signals implying that the assumption of profit maximization is accepted. However, when agrochemicals are applied improperly, they can generate external effects on human health and the environment. While external effects, or externalities, may also be positive, in this case they are negative.

Externalities are not only technological (that is, affecting the production technology of other economic factors), but they can also operate through spillover effects on the utility of

\section{Trang 30}


individuals. The externality concept is a broad one; on the environmental level it covers all forms of pollution, ranging from industrial and municipal sources in both urban and rural areas to consumption activities. However, this paper focuses only on the externalities agricultural production.

Externalities are usually engendered from pollution generation functions, which are also called non-point emission functions, associated with the production of an agricultural commodity (Zilberman et al., 1993). These functions represent the physical relationship between inputs used in agricultural production, such as agrochemicals and the level of their emissions to the environment. Let $E_{i}=h_{i}(Q, X, Z, R, S, T)$ be the pollution generation function related to a farm's production of a homogenous output (for example, rice). The emission $E_{i}$ of externality by farm $\mathrm{i}$ is thus denoted as a function of its common inputs (for example, labour, seed, water) $(X)$, environmental inputs (such as soil quality, and weather) $(R)$, output $(Q)$, environmental conditions $(R, S)$ and the state of technology ( $T$ ). However, only some inputs used in the production process generate emissions. For example, nitrogen fertilizers and pesticides often result in detrimental environmental externalities. Further specification of production technology, regular inputs, could be portioned in two groups, namely, $X_{1}$ and $X_{2}$. Inputs in group $X_{2}$ are denoted as 'polluting' inputs (that is, generating externalities). The level of emissions relates to the use of polluting inputs only, that is, $E_{i}=h_{i}\left(X_{2}\right)=h_{i}\left(Q, X_{1}, X_{2}, Z, R, S, T\right)$. Then, total emissions in the environment will be the sum of emissions at farm level. In practice, however, the individual emissions are difficult to identify and measure. A situation like this is referred to in the literature as non-point source (NPS) pollution. In agriculture, NPS pollution relates mostly to emissions by small sources such as farmers or farm households and includes nutrient contamination and pesticide pollution.

Pollution can cause two types of damage. The first and most observation is the detrimental effect on production processes of other firms, thereby reducing their productivity. The second is deterioration of environmental quality, including ambient air quality, natural habitat, biodiversity, and human health. For example, the use of pesticides on farms causes emissions, which eventually reach and contaminate surface water and groundwater. The resulting polluted water could reduce fish or shrimp production in the ponds of other producers, and increase the cost of purification of water treatment plants. Such costs to the society are not reflected in the private profits of farms.

\subsection{Effects of pesticides on environment}

Pesticides can have adverse effects on human health and the environment, both private and social. Direct exposure to pesticides can reduce farm productivity through the effects on farmers' health. Recent studies in the 
Philippines, Vietnam and China have found that both visible acute health impairment and invisible chronic health diseases in rice farmers are positively and significantly related to the extent of their exposure to pesticides. Acute (or short-term) effects generally occur immediately after improper application of pesticides, and are well documented. Figure 1, shows the reported signs and symptoms of pesticide poisoining in rice farmers in the Mekong Delta (Dung, 2007). Chronic effects, on the other hand, may develop over a long period of time after initial or long-term exposure to pesticides. Evidence of chronic effects, such as on kidneys, liver and the nervous system was also found among rice farmers exposed to pesticides for a long period. Thus, the costs of recovering health after pesticide exposure may completely offset the gains from reduction in rice yield losses. In most studies, health costs were only minimally estimated for farmers who were directly exposed to pesticides. Therefore, the health of children and women on the farm, and people living nearby or even far away, is also at risk. However, there has been no research into the aggregate health impacts of pesticide application nor are any data available on farm workers' exposure to pesticides globally. In addition to its negative effects on human health, the application of pesticides has the potential to cause a wide range of damage to the environment. Some types of pesticides degrade slowly in soil and water and may persist and accumulate in aquatic organisms and ecosystems. Moreover, when pesticides are applied in rice fields, it is not only pests that are killed but also predator or beneficial organisms. All this leads to changes in the biodiversity of production systems and aquatic ecosystems, with possibly long-term negative consequences.

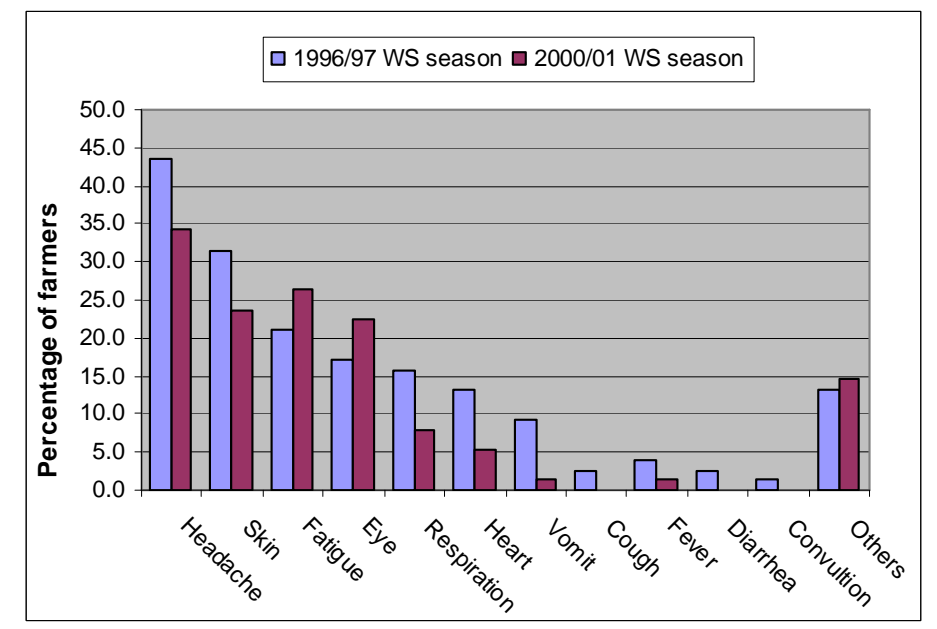

Figure 1. Reported signs \& symptoms of pesticide poisoning in the Mekomg Delta

\section{Trang 32}




\subsection{Effects of fertilizers on environment}

Like pesticides, fertilizers are among the primary agricultural non-point pollutants damaging the environment; their negative effects include eutrophication of surface water, nitrate accumulation in groundwater, and unwanted enrichment of the atmosphere with ammonia and nitrous oxide $\left(\mathrm{N}_{2} \mathrm{O}\right)$. Nitrogen and phosphorus originated from the soil into surface water (for example, streams, lakes and estuaries) at high rates cause excessive growth of algae and aquatic plants, the phenomenon known as eutrophication. The decomposition of these algae and plants produces unpleasant odours and reduces the oxygen supply available in surface water, which has a negative effect on the health of fish and other forms of aquatic life.

Excessive nitrogen can also reduce the quality of drinking water (in terms of taste, odour and nitrate concentration). Nitrogen in nitrate form $\left(\mathrm{NO}_{3}{ }^{-}-\mathrm{N}\right)$ easily leaches below the root zone into ground water or runs off into surface water. Drinking water drawn from these contaminated sources is potentially dangerous to human health, especially that of newborn infants. In the Mekong Delta, many people still draw drinking water from rivers and canals without any nitrate filtration. Nitrate in samples of surface water exceeds the limit of $10 \mathrm{mg} / \mathrm{L}$ nitrate-nitrogen set by the Vietnamese government for water used for human consumption. However, no data are available on deaths and health problems related to nationwide or even local nitrate contamination.
A third category of environmental problems is volatilization of ammonia $\left(\mathrm{NH}_{3}\right)$ from two chemical fertilizers, urea and ammonium sulphate. The emission of $\mathrm{N}_{2} \mathrm{O}$ gas into the air contributes to destruction of the ozone layer and acidification.

\section{ANALYTICAL FRAMEWORK}

The concept of sustainability of intensive rice cultivation and agricultural externality discussed above provides the background for establishing the analytical framework in this paper. Figure 2 is a schematic representation of the main relationships between the use of agrochemicals, productivity, profitability, environmental problems, and agricultural and environmental policy in rice production. Only relationships relevant to the objective of this paper are displayed. The effects to be considered in the analysis are shown by arrows.

Farm household decisions about the use of agrochemicals in rice production are influenced by factors which can be categorized into two groups: biophysical conditions and socioeconomic context. Biophysical conditions refer to nature-oriented factors and processes that influence rice production and harvesting, such as precipitation, temperature, soil fertility, water and nutrient regimes, nitrogen uptake and rice growth, pest population, population of other organisms (for example, beneficial insects and bacteria) and accumulation and leaching of pollutants. These factors determine the rice yield and externalities arising from the use of agrochemicals. The socioeconomic context refers to human-influenced factors and 
mechanisms, such as prices of inputs and outputs, market and institutional arrangements, property rights, and production technology. households about application of agrochemicals and other inputs at different levels to obtain the desirable rice yield.

These influence the decisions of farm

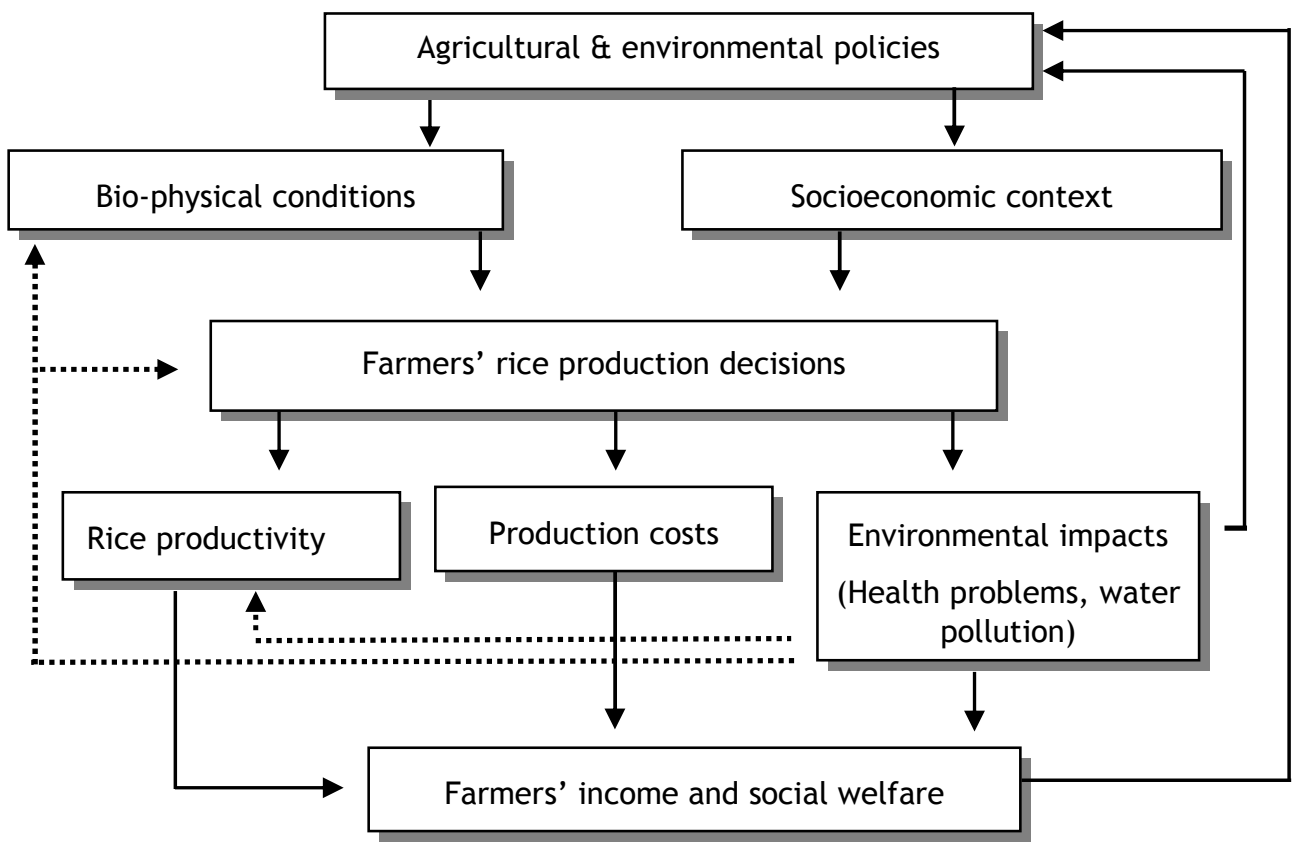

Notes: Direct analysis: $\longrightarrow$; Feedback: ….......

Figure 2. Linkage between production, farmers' income, environment \& policy

On the basis of prevailing biophysical conditions and the socioeconomic context, farm households take decisions about the type and level of agrochemical use, timing of fertilizer and pesticide application and the use of labour. Because of higher rice yield and a rise in the number of crops grown per year, farmers need to replenish soil nutrients frequently. The rice yield is considerably influenced by the quantity of nutrients supplied, usually in the form of chemical fertilizers, the method and timing of fertilizer application, and response of the rice crop to the fertilizers. Under-supply of nutrients may lower the yield while over-supply would result in higher production costs and increased damage to the environment. Pest problems during the growing season and pest management practices also affect the yield. Inappropriate use of pesticides leads to higher quantities being applied, high production costs, water pollution and increased health costs to farmers. Farm labour productivity and overall farm productivity are affected when health problems arise. Communal health is also impaired through contamination of surface and underground drinking water sources by pesticide and fertilizer residuals. On the other

\section{Trang 34}


hand, insufficient application of agrochemicals can result in lower yields, and, hence, income losses.

The existence of health and environmental problems generated by the use of agrochemicals, along with reduced social welfare, makes reform of current agricultural and environmental policies imperative. Such reform should aim to establish a new interrelation between agrochemical use by farm households, production, profitability and the environment. Figures in Table 1 show the interactive effects of alternative policies to control fertilizers $\left(\mathrm{F}_{\text {Tax }}\right)$, pesticides $\left(\mathrm{P}_{\text {Tax }}\right)$, and rice price increase $\left(R_{\text {sub }}\right)$ on total farmers' gains (Dung, 2007).

Table1.Estimated total benefits under various policy scenarios (VND/ha/crop)

\begin{tabular}{|c|c|c|c|c|c|}
\hline & Policy scenarios & $\begin{array}{c}\text { Farmers' net benefit } \\
\text { (1) }\end{array}$ & $\begin{array}{c}\text { Tax } \\
\text { collected (2) }\end{array}$ & $\begin{array}{c}\text { Government cost } \\
\text { (3) }\end{array}$ & Total impact \\
\hline (P1) & $\mathbf{R}_{\text {sub }}$ & 427,998 & 0 & 412,229 & $-15,769$ \\
\hline (P2) & $\mathbf{F}_{\text {Tax }}$ & 2,781 & 92,901 & 0 & 95,681 \\
\hline (P3) & $\mathbf{P}_{\text {Tax }}$ & 776 & 33,437 & 0 & 34,203 \\
\hline
\end{tabular}

Notes: Tax collected $=$ post-input demand $\mathrm{X} \%$ increase in input market price.

Government cost $=$ post-rice yield $\mathrm{X} \%$ increase in rice price.

Total impact $=(1)+(2)-(3)$.

\section{LEVEL OF ANALYSIS}

It is advisable to start analysis of economic and environmental consequences of agrochemicals and other inputs used in agricultural production at the farm level. This is because it is at the level of the individual farm that actual decisions are made about cropping patterns, production and input intensities and so forth. Since the Green Revolution, agriculture has been more dependent on external inputs such as pesticides, fertilizers, irrigation water and energy. 'Sustainable agriculture strives for integrated use of a wide range of these input management technologies by regenerating internal resources more effectively, minimizing the external inputs use, and greater using of local knowledge' (Pretty, 1995: 19-24). All these inputs, Pretty suggests, are integrated at the individual farm level in a strategy specific to the biological and socioeconomic conditions there. Each farmer weighs the trade off between short-run private benefits and long-run environmental protection. However, environmental degradation often imposes spillover or externality costs on other people and economic activities, and if the externality costs are significant, the level of environmental degradation that may be considered acceptable to farmers may be unacceptable at higher hierarchical, as regional, national, and international levels.

The main focus of the analysis is therefore on the farm household level. A number of 
conceptual considerations justify this focus in the Vietnamese context.

(a) In the transition from central planning to a market economy, rice farm households have emerged as autonomous economic units.

(b) Rice production in Vietnam is mainly undertaken by individual rural farm households.

(c) Farmers make the main decisions regarding allocation and use of resources, and marketing of products.

(d) Negative effects of agrochemical usage in rice production originate at the farm level.

(e) Policy instruments to reduce agricultural externalities (for example, water quality) will only be successful if they are implemented at the farm level.

\section{CONCLUSION}

Agrochemicals are used intensively in ricegrowing countries that have adopted Green Revolution technology. While the benefits of agrochemical use in agriculture are clear, their emissions into the soil, water and air have had severe negative effects on human health and the environment. This paper has presented an analytical framework appropriate for Vietnamese agriculture for the analysis of agrochemical use and its economic and environmental consequences based on the basic concepts of sustainability, intensive rice production, and agricultural externality.

Environmental costs associated with inappropriate use of chemical fertilizers and pesticides have not been measured and explicitly included in prevailing pricing systems. Therefore, current economic analysis may overestimate the profitability of rice production and thereby farm households' income, and may not keep up with the public concern over the trade-off between agricultural production and potential health hazards and environmental consequences. This makes it difficult for policymakers to design and analyze the effects of alternative environmental policies on farmers' private costs and costs in relation to the environment. Thus, a thorough analysis of the sustainability of rice production would have to include not only valuations of private and social costs, but also an examination of the impact of changes in policy instruments on production, farmers' income and the environment.

The perspective adopted by this paper is relevant to the current debates on economic and environmental issues surrounding agrochemical use in Vietnamese agriculture. It is significant for several reasons. First, Vietnam is in transition to a market economy and economic policy reforms, especially market liberalization, have played an important role in expanding rice production. As a result, Vietnam has attained food self-sufficiency after emerging from a state of near-famine and has become the second-largest rice exporter in the world. Second, the performance of the Vietnamese rice sector affects the social and economic wellbeing of rural communities, as more than two-thirds of the rural households are engaged in growing rice and rice accounts

\section{Trang 36}


for three-quarters of the caloric intake of households. Third, the use of agrochemicals at farm level is examined in terms of both, private profitability of farmers and the possible negative effects on the environment. Thus, the analytical framework is relevant to policymaking. Finally, the paper is expected to contribute a new perspective to analysis of Vietnam, in that it takes into account the relationship between technical, economic and environmental aspects and policy in one integrated analysis, something that has not been done in the literature so far.

\title{
KHUNG PHÂN TÍCH SỰ BỀN VṸNG CỦA SẢN XUÂT LÚA THÂM CANH VÀ SINH KẾ CỦA NÔNG DÂN
}

\author{
Nguyễn Hũu Dũng \\ Trường Đại học Kinh tế Tp.HCM
}

TÓM TÄT: Tại nhiều hệ thống thâm canh sản xuất lúa gạo trên thế giới, việc sủ dụng các hóa chất nông nghiệp (phân bón hóa học và thuốc bảo vệ thục vật) đã cho thấy hai kết quả trái nguợc nhau: một mặt là làm gia tăng sản luợng và mặt khác là ảnh huởng xấu đến sức khỏe nguời dân và môi truờng. Mục tiêu của bài viết này là xây dựng một khung phân tích để đo lường, xem xét khía cạhh bền vũng của việc sử dụng hóa chất nông nghiệp và tác động của nó đến môi truờng. Khung phân tích được thiết lập dụa trên các khái niệm về thâm canh sản xuất lúa, ngoại tác tiêu cực trong sản xuất nông nghiệp, và phát triển bền vũng đã đượ vận dụng để đưa ra một tầm nhìn rộng và tập trung đến sự phát triển. Do vậy, bài báo đã phân tích tổng hợp toàn cảnh mối quan hệ giũa các khía cạnh kỹ thuật, kinh tế, môi truờng, và chính sách, mà điều này chura được đề cập trong các nghiên cúu truớc đây tại Việt Nam. Lợi ích riêng cho nông dân trồng lúa, và các ảnh huởng xấu có thể có của việc sủ dụng các hóa chất nông nghiệp được đề xuất là nên nghiên cúu tại cấp nông hộ.

Tù khóa: hóa chất nông nghiệp, sản xuất lúa thâm canh, phát triển bền vũng

\section{REFERENCES}

[1]. Conway, G.R. and J.N. Pretty (1991) Unwelcome Harvest: Agriculture and Pollution, pp. 1-16. London: Earthscan Publications Ltd.

[2]. Dung, N. H. (2007) Economic and Environmental
Agrochemical Use for Intensive Rice production in the Mekong Delta, Vietnam. Shaker Publishing BV, The Netherlands.

[3]. Opshoor, J.B (2002) 'Sustainability: A Robust Bride over Intertemporal Societal Dividies?', in P.V. Seters, B. de G. Fortman, and A. de Ruijter (eds) 
Globalization and Its new Dividers: Malcontents, Recipes, and Reform, pp. 7999. Amsterdam: Dutch University Press.

[4]. Pretty, J. (1995) Regenerating Agriculture: Policy and Practice for Sustainability and Self-Reliance, pp. 27-57. London: Earthscan Publications Ltd.

[5]. WCED (1987) Our Common Future. New York: Oxford University Press.

[6]. Wossink, G.A.A., G.H. Peters and G.C. van Kooten (1998) 'Introduction to Agrochemicals Use', in G.A.A. Wossink,
G.H. Peters and G.C. van Kooten (eds)

Economics of Agrochemicals: An International Overview of Use Patterns, Technical and Institutional Determinants, Policies and Perspectives, pp. 1-40, London: Ashgate Publishing Ltd.

[7]. Zillberman, D. and M. Marra (1993) 'Agricultural Externalities', in G. A. Carlson, D. Zilberman and J.A. Miranowski (eds) Agricultural and Environmental Resource Economics. Oxford: Oxford University Press. 